\title{
PROBLEMATIKA HUKUM UNDANG-UNDANG NO.12 TAHUN 2011 TENTANG PEMBENTUKAN PERATURAN PERUNDANG-UNDANGAN
}

\author{
Retno Saraswati \\ Fakultas Hukum Universitas diponegoro Semarang \\ Email: saraswariretno@yahoo.co.id
}

\begin{abstract}
In the development of national law must be supported by certain means and methods, raw, and standards that bind all authorized institutions that make laws. Law. 12 Year 2011 on the establishment of legislation is the only guide in the formation of legislation in Indonesia. However, the Act was also raises problems of law, both at the level of the rules as well as at the level of praxis. Therefore we need a solution in the form of new regulation and changes of the rules themselves.
\end{abstract}

Keywords: development of national law, formation of legislation, legal problems,

\begin{abstract}
Abstrak
Pembangunan regulasi nasional harus didukung oleh beberapa hal diantaranya adalah metode, materi dan standar yang mengikat seluruh institusi yang berkepentingan didalam pembuatan hukum. UndangUndang Nomor 11 Tahun 2011 tentang Pembentukan Peraturan Perundang-undangan merupakan satu-satunya panduan didalam pembuatan perundangan yang ada di Indonesia. Hal ini mengakibatkan undang-undang pun dapat menimbulkan persoalan hukum, baik dari sisi aturan maupun implementasi dari aturan tersebut. Oleh karenanya, diperlukan solusi terhadap pembentukan regulasi dan perubahan didalam regulasi itu sendiri.
\end{abstract}

Kata Kunci: pengembangan regulasi nasional, pembentukan perundang-undangan, persoalan hukum,

\section{A. Pendahuluan}

Lahirnya UU No. 12 Tahun 2011 tentang Pembentukan Peraturan Perundang-undangan merupakan upaya penyempurnaan dari undangundang sebelumnya yakni UU No. 10 Tahun 2004 tentang Pembentukan Peraturan Perundangundangan. Terbitnya UU No. 12 Tahun 2011 tentunya berdampak pada aspek hukumnya , selain memberikan pedoman yang semakin jelas dan pasti terhadap hal-hal yang tadinya belum jelas diatur, akan tetapi juga memunculkan persoalan-persoalan hukum baru, misalnya saja dengan masuknya Ketetapan MPR dalam tata urutan peraturan perundang-undangan. Terkait dengan masalah pengujian, siapakah yang berhak menguji terhadap Ketetapan MPR tersebut, dan masih banyak lagi problematika atau permasalahan hukum yang muncul.

Di dalam konteks negara yang berdasarkan atas hukum, maka problematika atau permasalahan hukum yang muncul harus segera mendapatkan solusi, agar ada kepastian hukumnya. Problematika yang muncul tersebut dapat disebabkan oleh ketidak jelasan dalam pengaturan atau belum lengkapnya dalam pengaturan atau sebab yang lain dalam pembentukan peraturan perundangundangan.

\section{B. Metode Penelitian}

Sajian tulisan ini merupakan hasil penelitian, yang dalam melakukan penelitiannya menggunakan metode yuridis normatif. Penulis hanya melakukan penelitian kepustakaan, dalam hal ini meneliti bahan hukum yang diperoleh melalui studi dokumen dengan cara membaca, mengutip, menyadur, dan membandingkan terhadap beberapa bahan hukum primer yang berupa peraturan perundang-undangan, serta bahan hukum sekunder yang berupa hasil penelitian dan literatur yang relevan. Selanjutnya hasil dari penelitian dianalisis dengan menggunakan metode deduktif dan selanjutnya dituangkan dalam bentuk laporan penelitian.

\section{Hasil Penelitian dan Pembahasan}

1. Pijakan Konsep dan Teori

Adapun teori dan konsep yang dipakai sebagai pisau analisis, meliputi: Pertama, Prinsip Otonomi daerah dalam Kerangka Negara Kesatuan Republik Indonesia. Pasal 18 UUD 1945 menegaskan mengenai hubungan antara Pusat dan daerah dengan politik hukum desentralisasi (otonomi). Prinsip otonomi daerah menggunakan prinsip otonomi 
seluas-luasnya dalam arti daerah diberikan kewenangan mengurus dan mengatur semua urusan pemerintahan di luar yang menjadi urusan Pemerintah. Sejalan dengan prinsip tersebut dilaksanakan pula prinsip otonomi yang nyata dan bertanggungjawab. Pada saat ini sesuai dengan amanat UUDNRI Tahun 1945 dan UU No. 32 Tahun 2004 tentang Pemerintahan daerah, pemerintah daerah berwenang untuk mengatur dan mengurus sendiri urusan pemerintahan menurut asas otonomi dan tugas pembantuan. Pemberian otonomi luas kepada daerah diarahkan untuk mempercepat terwujudnya kesejahteraan masyarakat melalui peningkatan pelayanan, pemberdayaan dan peran serta masyarakat. Di samping itu melalui otonomi luas, daerah diharapkan mampu meningkatkan daya saing dengan memperhatikan prinsip demokrasi, pemerataan, keadilan, keistimewaan dan kekhususan serta potensi dan keanekaragaman daerah dalam sistem Negara kesatuan Republik Indonesia. Untuk itu Pemerintahan daerah berhak menetapkan peraturan daerah dan peraturan-peraturan lain untuk melaksanakan otonomi dan tugas pembantuan.

Kedua, Asas Peraturan Perundangundangan. Asas hukum bukanlah norma hukum konkrit, tetapi asas hukum sangat penting artinya dalam pembentukan dan pemberlakuan hukum. Asas hukum adalah aturan dasar yang melatarbelakangi lahirnya norma hukum konkrit dan pelaksanaan hukum. Jadi asas hukum merupakan jantungnya hukum, atau sebagai bintang pemandu pembentukan dan pelaksanaan hukum. Apabila dalam sistem hukum terjadi pertentangan atau terjadi konflik norma, maka asas hukum akan tampil untuk mengatasinya (Jazim Hamidi, 2008:15).

Dalam membentuk peraturan perundangundangan harus berdasarkan pada asasasas pembentukan peraturan perundangundangan sebagai berikut :

a. Asas pembentukan peraturan perundangundangan.

b. Asas materi muatan peraturan perundang-undangan.

c. Asas lain sesuai dengan bidang hukum peraturan perundang-undangan yang bersangkutan.

Di samping itu masih ada asas lain yang harus juga diperhatikan, yakni asas hukum yang bersifat umum, ialah asas hukum yang berhubungan dengan semua bidang hukum, contoh :

a. Asas lex posteriori derogat legi priori

b. Asas lex specialis derogat legi generali, dan lain sebagainya.

Ketiga, Prinsip Hierarkis Peraturan Perundang-undangan. Menurut Hans kelsen, norma hukum adalah aturan, pola, atau standar yang perlu diikuti (Jazim Hamidi, 2008:21). Dalam kaitannya dengan hierarki norma hukum, Hans Kelsen mengemukakan teorinya mengenai jenjang norma hukum (Stufenbautheorie) sebagaimana disitir oleh Maria Farida dalam bukunya IImu Perundangundangan (Maria Farida Indrati Soeprapto, 1998:25), dimana ia berpendapat bahwa norma-norma hukum itu berjenjang-jenjang dan berlapis-lapis dalam suatu hierarki tata susunan, di mana suatu norma yang lebih rendah berlaku, bersumber, dan berdasar pada norma yang lebih tinggi, norma yang lebih tinggi, berlaku, bersumber dan berdasar pada norma yang lebih tinggi lagi, demikian seterusnya sampai pada suatu norma yang tidak dapat ditelusuri lebih lanjut dan bersifat hipotetis dan fiktif, yaitu Norma Dasar (grundnorm). Norma Dasar yang merupakan norma tertinggi dalam sistem norma tersebut tidak lagi dibentuk oleh suatu norma yang lebih tinggi lagi, tetapi Norma dasar itu ditetapkan terlebih dahulu oleh masyarakat sebagai Norma dasar yang merupakan gantungan bagi norma-norma yang berada di bawahnya sehingga suatu Norma Dasar itu dikatakan pre-supposed.

Hans Nawiasky mengatakan bahwa suatu norma hukum dari negara manapun selalu berlapis-lapis dan berjenjang-jenjang (Maria Farida Indrati Soeprapto, 1998:27), namun bedanya dengan teori Hans Kelsen, bahwa Hans Nawiasky telah mengelompokkan norma-norma hukum dalam suatu negara itu menjadi empat kelompok besar yang terdiri atas:

Kelompok I: Staatsfundamentalnorm (Norma Fundamental Negara)

Kelompok II : Staatsgrundgesetz (Aturan dasar/Pokok Negara)

Kelompok III : Formell Gesetz (Undangundang formal)

Kelompok IV: Verordnung dan Autonome Satzung (Aturan pelaksana dan aturan otonom).

Kelompok-kelompok norma hukum tersebut hampir selalu ada dalam tata susunan norma hukum setiap negara 
walaupun mempunyai istilah yang berbedabeda ataupun jumlah norma hukum yang berbeda dalam setiap kelompoknya.

Teori Hans Kelsen dan Hans Nawiasky ini mengilhami bagaimana pengaturan norma hukum di Indonesia. Jika kita lihat dalam UU No. 12 tahun 2011, dalam Pasal 7 Ayat (1) dan (2) dapat kita temukan adanya hierarki dalam norma hukum kita. Hal ini dapat kita cermati adanya jenis dan hierarki Peraturan Perundang-undangan (Pasal 7 Ayat (1) UU N0. 12 Tahun 2011) yang terdiri atas:

a. Undang-Undang Dasar Negara Republik Indonesia Tahun 1945;

b. Ketetapan Majelis Permusyawaratan Rakyat;

c. Undang-Undang/Peraturan Pemerintah Pengganti Undang-Undang;

d. Peraturan Pemerintah;

e. Peraturan Presiden;

f. Peraturan Daerah Provinsi; dan

g. Peraturan Daerah Kabupaten/Kota.

Kekuatan hukum Peraturan Perundangundangan sesuai dengan hierarki. Dengan demikian Undang-Undang Dasar Negara Republik Indonesia Tahun 1945 merupakan hukum dasar tertulis yang tertinggi yang harus menjadi dasar dan sumber bagi pembentukan peraturan-peraturan yang berada di bawahnya, dan peraturan yang berada dibawah harus mendasarkan dan bersumber serta tidak boleh bertentangan pada peraturan yang berada di atasnya.

Keempat, Sistem Pengujian Peraturan Perundang-undangan. Pengujian peraturan perundang-undangan adalah salah satu mekanisme untuk tetap menjaga adanya konsistensi antara peraturan perundangundangan. Secara teoretis, pembentukan dan pengujian peraturan perundang-undangan disandarkan pada ajaran Hans kelsen, Dalam kerangka demikian ajaran stufenbautheorie dapat dijadikan pijakan untuk melakukan judicial review. Mahkamah Agung dan Mahkamah Konstitusi sebagai pelaksana kekuasaan kehakiman dapat berperan obyektif dalam melakukan kontrol terhadap tindakan hukum legislatif dan eksekutif dalam upaya menerapkan teori norma hukum berjenjang dalam pengujian peraturan perundang-undangan.

Pengertian judicial review dalam bahasa Inggris hanya berkaitan dengan pengujian peraturan di bawah undang-undang atau pengujian terhadap norma hukum yang bersifat konkrit seperti kita kenal di Indonesia dengan perkara-perkara tata usaha negara. Karena itu, yang dimaksud oleh A.W. Bradley dan K.D Ewing (Jimly Asshiddiqie, 2006:157) adalah grounds of review relating to the substance or content of the official decision or action that is under review, artinya obyek pengujian (judicial review) yang dimaksud dapat berupa acts atau actions dari pejabat negara yang berwenang untuk itu, yang apabila dipandang merugikan warga negara dapat digugat di pengadilan.

Judicial review yang terjadi di Indonesia adalah pengujian peraturan (regels) bukan pengujian atas keputusan-keputusan yang bersifat administratif (beschikking). Pengujian peraturan yang berbentuk undang-undang terhadap undang-undang dasar dilakukan oleh Mahkamah Konstitusi. Sedangkan pengujian peraturan perundang-undangan di bawah undang-undang terhadap undang-undang dilakukan oleh Mahkamah Agung. Pengujian atas keputusan-keputusan adminstratif atau tata usaha negara dilakukan oleh Pengadilan Tata Usaha Negara.

Kelima, Teori Hukum responsif. Philippe Nonet dan Philip Selznick mengajukan suatu teori yang bertujuan untuk menjelaskan hubungan-hubungan sistemik dalam hukum dan konfigurasi-konfigurasi khusus,mengembangkan pemahamannya tentang betapa kompleksnya kenyataan antara hukum dan masyarakat. Philippe Nonet dan Philip Selznick (Philippe Nonet dan Philip Selznick, (terjemahan), 2008: 33-115) membedakan tiga keadaan dasar mengenai hukum dalam masyarakat, yaitu: a) Hukum Represif : hukum sebagai alat kekuasaan represif; b) Hukum Otonom : hukum sebagai suatu pranata yang mampu menetralisir represi dan melindungi integritas hukum itu sendiri; c) Hukum Responsif : hukum sebagai suatu sarana respons terhadap ketentuan-ketentuan sosial dan aspirasiaspirasi masyarakat.

\section{Problematika Undang-Undang Nomor 12 Tahun 2011}

Indonesia adalah negara yang berdasarkan atas hukum, yang memiliki makna bahwa segala sesuatu di negara ini senantiasa harus berdasarkan pada hukum. Segala aspek kehidupan dalam bidang kemasyarakatan, kebangsaan, dan kenegaraan termasuk pemerintahan harus berdasarkan atas hukum. Oleh karena itu 
pembentukan hukum sangatlah penting bagi kehidupan bernegara yang mendasarkan pada hukum. Negara berkewajiban melaksanakan pembangunan hukum nasional secara terencana, terpadu, dan berkelanjutan dalam sistem hukum nasional. Dalam rangka pembangunan hukum nasional perlu didukung oleh cara dan metoda yang pasti, baku dan standart yang mengikat semua lembaga yang berwenang membuat peraturan perundang-undangan. Salah satu upaya yang dilakukan oleh negara adalah dengan membuat pedoman dalam pembentukan peraturan perundang-undangan, yakni dengan membentuk Undang-Undang Nomor 12 Tahun 2011 tentang Pembentukan Peraturan Perundang-undangan. Undangundang tersebut merupakan satu-satunya pedoman dalam pembentukan peraturan perundang-undangan.

UU No. 12 Tahun 2011 tentang Pembentukan Peraturan Perundangundangan ini menggantikan undang-undang sebelumnya yakni UU No. 10 Tahun 2004 tentang Pembentukan Peraturan Perundangundangan. Ada hal-hal baru yang diatur dalam undang-undang yang baru tersebut antara lain masuknya Ketetapan MPR dalam tata urutan perundang-undangan, dimana Ketetapan MPR dalam tata urutan peraturan perundangundangan diletakkan setelah Undang-Undang Dasar Negara Republik IndonesiaTahun 1945. Kemudian diaturnya perencanaan pembentukan peraturan perundangundangan, tidak hanya untuk pembentukan undang-undang, akan tetapi juga untuk pembentukan peraturan pemerintah dan peraturan presiden. Selanjutnya mengenai tahapan dalam pembahasan undangundang yang hanya dalam dua tingkatan saja, kemudian keharusan adanya naskah akademis dalam pembentukan undangundang dan peraturan daerah, juga diatur bagaimana pedoman pembuatan naskah akademiknya, dan juga diaturnya masalah partisipasi dengan lebih jelas lagi.

Namun demikian UU No. 12 Tahun 2011 pada kenyataannya masih memunculkan beberapa problematika hukum, antara lain

: Pertama, dengan perubahan pada jenis dan hierarki peraturan perundang-undangan sebagaimana diatur dalam Pasal 7 Ayat (1) UU No. 12 Tahun 2011, yang memasukkan Ketetapan Majelis Permusyawaratan Rakyat dalam urutan kedua setelah UUDNRI Tahun 1945, maka apabila ada UU yang bertentangan dengan Ketetapan MPR atau ada Ketetapan MPR yang bertentangan dengan UUDNRI Tahun 1945, belum diatur mekanisme pengujiannya.

Ketetapan MPR yang dimaksud dalam Pasal 7 Ayat (1) UU No. 12 Tahun 2011 adalah Ketetapan MPR Sementara dan Ketetapan MPR yang masih berlaku sebagaimana dimaksud dalam Pasal 2 dan Pasal 4 Ketetapan MPR Nomor: I/MPR/2003 tentang Peninjauan Terhadap Materi dan Status Hukum Ketetapan Majelis Permusyawaratan Rakyat Sementara dan Ketetapan Majelis Permusyawaratan Rakyat Tahun 1960 sampai dengan Tahun 2002 (Penjelasan Pasal 7 Ayat (1) Huruf b UU No. 12 Tahun 2011). Dengan demikian tidak seluruh Ketetapan MPR dapat dijadikan dasar hukum dalam pembentukan peraturan perundang-undangan di Indonesia.

Ketetapan MPR merupakan staatsgrundgesetz atau Aturan Dasar Negara/ Aturan Pokok Negara, yang berisi garis-garis besar atau pokok-pokok kebijaksanaan negara, sifat norma hukumnya masih secara garis besar, dan merupakan norma hukum tunggal dan tidak dilekati oleh norma hukum sekunder. Sifat-sifat norma yang ada dalam Ketetapan MPR ini sebenarnya sama dengan yang ada dalam Pasal-Pasal UUD, itu sebabnya norma dalam Ketetapan MPR dapat mengisi atau melengkapi norma UUD.

Dengan tidak diaturnya mengenai mekanisme pengujian tersebut jelas dalam kehidupan bernegara terjadi adanya ketidak pastian hukumnya terkait dengan pengujian terhadap Ketetapan MPR maupun UU yang bertentang dengan Ketetapan MPR, maka solusinya adalah satu-satunya yang memungkinkan adalah mekanisme pengujiannya melalui Mahkamah konstitusi. Alasannya bahwa dalam hierarki peraturan perundang-undangan Ketetapan MPR terletak di bawah UUDNRI Tahun 1945 dan di atas Undang-Undang/Peraturan Pemerintah Pengganti Undang-Undang, padahal pengujian terhadap Undang-Undang yang bertentangan dengan UUDNRI Tahun 1945 melalui Mahkamah Konstitusi, sehingga logis jika pengujian terhadap Ketetapan MPR adalah melalui Mahkamah Konstitusi, bukan ke Mahkamah Agung karena Mahkamah Agung diperuntukkan bagi pengujian peraturan di bawah Undang-Undang yang bertentangan dengan Undang-Undang (Pasal 9 Ayat (1) dan (2)). 
Kedua, di dalam Pasal 8 Ayat (1) UU No.12 Tahun 2011diatur mengenai jenis Peraturan Perundang-undangan selain sebagaimana dimaksud dalam Pasal 7 Ayat (1) diakui keberadaannya dan mempunyai kekuatan hukum mengikat sepanjang diperintahkan oleh Peraturan Perundang-undangan yang lebih tinggi atau dibentuk berdasarkan kewenangan. Dengan demikian hampir semua lembaga negara juga berwenang untuk mengeluarkan peraturan yang diakui secara sah. Permasalahannya, kedudukannya lebih tinggi yang mana antara Peraturan Perundangan-undangan yang dibentuk oleh lembaga negara tersebut jika dipersandingkan dengan jenis Peraturan Perundangan-undangan sebagaimana diatur dalam Pasal 7 Ayat (1) UU No. 12 Tahun 2011, misalkan sebagai dasar hukum lebih tinggi mana kedudukannya antara Peraturan Bank Indonesia dengan Peraturan Pemerintah, karena dalam praktek sering terjadi hal yang demikian, sedangkan dalam UU No. 12 Tahun 2011 belum ada penjelasannya lebih lanjut. Sebagai contoh di dalam Peraturan Pemerintah No. 29 Tahun 1999, mengatur dengan memperbolehkan pihak asing dapat membeli maksimal 99\% saham di bank Lokal, sementara dalam Peraturan Bank Indonesia No. 14/8/PBI/2012 mengatur bahwa pihak asing dapat membeli maksimal hanya $40 \%$, dari kedua peraturan tersebut mana yang lebih tinggi kedudukannya.

Hal ini jelas akan menimbulkan kebingungan pada masyarakat bahkan bisa menyebabkan adanya ketidakpastian hukum, dalam konteks negara hukum hal yang semacam ini harus tidak boleh terjadi, maka solusinya yang Pertama, yang harus dilihat apakah peraturan tersebut dibentuk berdasarkan perintah dari peraturan perundang-undangan yang lebih tinggi atau dibentuk berdasarkan kewenangan. Kalau peraturan tersebut dibentuk diluar kriteria tersebut, maka peraturan tersebut dapat dikesampingkan, artinya kedudukannya lebih tinggi dari jenis peraturan yang ada dalam hierarki peraturan perundang-undangan. Kedua, dengan menggunakan asas-asas hukum umum, misalnya : lex specialis derogat lex generalis, bahwa jika peraturan yang mengatur hal yang merupakan kekhususan dari hal yang umum (dalam arti sejenis) yang diatur oleh peraturan yang sederajat, maka berlaku peraturan yang mengatur hal khusus tersebut dan lex posterior derogat lex priori, bahwa dalam hal peraturan yang sederajat bertentangan dengan peraturan sederajat lainnya (dalam arti sejenis), maka berlaku peraturan yang terbaru dan peraturan yang lama dianggap telah dikesampingkan.

Ketiga, kedudukan Peraturan Menteri. Terkait dengan Peraturan Menteri secara hukum diakui keberadaannya dan mempunyai kekuatan hukum mengikat sepanjang diperintahkan oleh Peraturan Perundangundangan yang lebih tinggi atau dibentuk berdasarkan kewenangan (Pasal 8 UU No.12 Tahun 2011). Namun dalam prakteknya banyak daerah dalam membentuk perda tidak mengacu pada Peraturan Menteri bahkan cenderung diabaikan dengan alasan tidak masuknya jenis Peraturan Menteri dalam jenis dan hierarki peraturan perundang-undangan di Indonesia.

Terkait dengan hal tersebut, maka solusinya Peraturan Menteri harus diakui dan dijadikan pedoman dalam pembentukan Peraturan Daerah. Alasannya : Pertama, Peraturan Menteri mempunyai kedudukan sebagai salah satu jenis peraturan perundang-undangan. Peraturan Menteri merupakan salah satu peraturan yang diakui keberadaannya dan mempunyai kekuatan hukum mengikat sepanjang diperintahkan oleh peraturan perundangundangan yang lebih tinggi atau dibentuk berdasarkan kewenangan (Pasal 8 UU No.12 Tahun 2011). Kedua, Menteri merupakan pembantu Presiden sesuai dengan ketentuan Pasal 17 ayat (1) Undang-Undang Dasar Negara Republik Indonesia Tahun 1945, dan dalam Pasal 17 ayat (3) dinyatakan bahwa Setiap Menteri membidangi urusan tertentu dalam pemerintahan. Dengan demikian, dari rumusan tersebut dapat dinyatakan ada kewenangan yang secara atributif (melekat) pada Menteri, sehingga sesuai dengan kewenangannya tersebut seharusnya melekat juga kewenangan untuk mengatur penyelenggaraan pemerintahan yang menjadi tugas dan fungsinya melalui Peraturan Menteri. Ketiga, Peraturan Menteri merupakan Peraturan Pusat yang harus dijadikan dasar hukum bagi pembentukan peraturan di tingkat daerah. Peraturan Menteri merupakan Peraturan Pusat yang dibuat oleh Pemerintah Pusat dan bersifat pelaksanaan terhadap peraturan yang lebih tinggi dan sekaligus merupakan pelaksanaan kewenangan pusat mempunyai kedudukan yang lebih tinggi dari peraturan yang dibuat di 
daerah. Sehingga pembuatan dan penetapan Peraturan Daerah (Perda) di daerah-daerah tentu harus mengacu kepada Peraturan Menteri. Lingkup berlakunya Peraturan Menteri adalah secara nasional artinya berlaku di seluruh wilayah Negara Kesatuan Republik Indonesia. Hanya saja Peraturan Menteri tersebut tidak perlu dicantumkan dalam konsideran mengingat (dasar hukum) perda, akan tetapi pencantumannya cukup dalam naskah akademiknya saja.

Keempat, dengan kedudukan Peraturan daerah Kabupaten/Kota dibawah Peraturan Daerah Provinsi dalam tata urutan peraturan perundang-undangan sebagaimana diatur dalam Pasal 7 Ayat (1) UU No. 12 Tahun 2011, sebagai konsekuensinya apakah sebelum dibentuk Perda Kabupaten/Kota harus terlebih dahulu ada Perda Provinsinya. Dalam praktek ada provinsi yang tidak memperbolehkan perda (kabupaten) tertentu dibuat dengan alasan perda provinsinya belum ada.

Jika yang terjadi demikian maka dampaknya bisa mengakibatkan adanya kevakuman hukum dan daerah tidak dapat mengatur hal yang urgen dalam rangka otonomi daerah, padahal dalam rangka menjalankan otonomi daerah diperlukan kesigapan dalam pengaturan hukumnya agar otonomi daerah dapat terselenggara dengan lancar.

Sebagai solusinya bahwa dalam Pembentukan Perda Kabupaten/Kota tidak harus menunggu adanya Perda Provinsi. Hal ini harus dipahami oleh pihak Provinsi dan Kabupaten/Kota, jangan sampai gara-gara Perda Provinsi belum mengatur lantas Perda Kabupaten/Kota tidak diperbolehkan, sehingga dapat mengganggu penyelenggaraan otonomi daerah. Prinsip otonomi daerah menggunakan prinsip otonomi seluas-luasnya dalam arti daerah diberikan kewenangan mengurus dan mengatur semua urusan pemerintahan di luar yang menjadi urusan Pemerintah, daerah memiliki kewenangan membuat kebijakan daerah untuk memberi pelayanan, peningkatan peranserta, prakarsa, dan pemberdayaan masyarakat yang bertujuan pada peningkatan kesejahteraan rakyat. Oleh sebab itu jika daerah merasa perlu mengatur suatu urusan dalam Perda guna menjalankan otonomi daerah tidak perlu ragu, dan Provinsi juga tidak boleh menghambat dengan alasan belum ada Perda provinsi yang mengatur hal tersebut. Hal ini juga sejalan dengan pemikiran dari Teori Hukum Responsif, Perda disini dibentuk sebagai fasilitator dari berbagai respon terhadap kebutuhan dan aspirasi sosial, hal tersebut menunjukkan kapasitas beradaptasi yang bertanggungjawab. Dalam konteks hukum responsif, maka daerah yang memiliki kapasitas politik berhak untuk menyelesaikan permasalahanpermasalahannya, menetapkan prioritasprioritasnya, dan membuat komitmenkomitmen yang dibutuhkan.

\section{d. Simpulan}

Berdasarkan pada hasil penelitian yang selanjutnya dilakukan pengkajian melalui teori dan konsep yang ada, maka dapat disimpulkan bahwa problematika hukum UU No.12 Tahun 2011 berikut solusinya adalah sebagai berikut :

1. Belum diaturnya mekanisme pengujian terhadap Ketetapan MPR yang bertentangan dengan UUDNRI Tahun 1945, maupun Undang-Undang yang bertentangan dengan Ketetapan MPR, maka solusinya mekanisme pengujian dapat dilakukan melalui Mahkamah Konstitusi.

2. Belum diaturnya atau tidak adanya penjelasan mengenai kedudukan jenis peraturan perundangan-undangan lain jika dipersandingkan dengan jenis peraturan yang diatur dalam hierarki peraturan perundangundangan, maka bisa dianalisis dengan melihat apakah peraturan tersebut dibentuk berdasarkan delegasi dan berdasarkan kewenangan serta menggunakan asas hukum umum.

3. Kurangnya pengakuan dari daerah terhadap Peraturan Menteri. Terkait dengan hal tersebut, maka Peraturan Menteri harus diakui dan dijadikan dasar dalam pembentukan Perda, dengan alasan bahwa peraturan Menteri merupakan bentuk peraturan yang diakui keberadaannya dan mempunyai kekuatan hukum mengikat sepanjang diperintahkan oleh peraturan perundang-undangan yang lebih tinggi atau dibentuk berdasarkan kewenangan, di samping itu Peraturan menteri merupakan jenis peraturan yang dibentuk oleh Pemerintah Pusat karena Menteri adalah pembantu Presiden yang membidangi urusan tertentu dalam pemerintahan.

4. Konsekuensi Hukum dari letak Peraturan Daerah Kabupaten/Kota yang berada di bawah Peraturan daerah provinsi. Dengan alasan prinsip otonomi dan mendasarkan pada teori hukum responsif, maka dalam pembentukan Perda Kabupaten/Kota tidak harus menunggu Perda provinsi 


\section{E. Saran}

1. Pembentuk UU segera melakukan pengaturan mengenai mekanisme pengujian terhadap Ketetapan MPR, memasukkan Peraturan Menteri dalam hierarki peraturan perundangundangan, dan memberikan penjelasan lebih lanjut tentang kedudukan peraturan selain dalam hierarki peraturan perundangundangan.

2. Pengaturan dan penjelasan tersebut bisa dilakukan dengan cara melakukan perubahan atau amandemen terhadap UU No. 12 Tahun 2011 tentang Pembentukan Peraturan Perundang-undangan.

\section{daftar Pustaka}

Abdul Latief. 2006. Hukum dan peraturan Kebijaksanaan (Beleidsregel) pada pemerintahan Daerah. Yogyakarta: UUI Press.

Agussalim Andi Gandjong. 2007. pemerintahan Daerah, Kajian politik dan Hukum. Bogor: Ghalia Indonesia.

Anis Ibrahim. 2008. Legislasi dan Demokrasi, Interaksi dan Konfigurasi Politik Hukum Dalam Pembentukan Hukum Di Daerah. Malang: In-TRANS Publishing.

Aos Kuswandi. 2004. pelaksanaan Fungsi Legislatif dan Dinamika politik DprD. Bekasi: LIP-FISIP UNISMA.

A. Rahman. 2007. Sistem politik Indonesia. Yogyakarta: Graha IImu.

Arbi Sanit. 1997. partai, pemilu dan Demokrasi. Yogyakarta: Pustaka Pelajar.

Djoko Prakoso. 1985. proses pembuatan peraturan Daerah dan Beberapa Usaha penyempurnaannya. Jakarta: Ghalia Indonesia.

Hanif Nurcholis. 2007. Teori dan praktek: pemerintahan dan Otonomi Daerah. Jakarta: Grasindo.

Jazim Hamidi. Dkk. 2008. Meneropong Legislasi di Daerah. Malang: Universitas Negeri Malang.

. 2008. pembentukan peraturan Daerah partisipatif. Jakarta: Prestasi Pustaka.

Jimly Asshiddiqie. 2006. perihal Undang-Undang. Jakarta: Konstitusi Press.

J. Kaloh. 2009. Kepemimpinan Kepala Daerah, pola Kegiatan, Kekuasaan, dan perilaku Kepala Daerah dalam pelaksanaan Otonomi Daerah. Jakarta: Sinar Grafika.

Juanda. 2004. Hukum pemerintahan Daerah, pasang Surut Hubungan Kewenangan antara DprD dan Kepala Daerah. Bandung: Alumni.

Khairul Muluk. 2006. Desentralisasi dan pemerintahan Daerah. Jakarta: Bayumedia.

Maria Farida Indrati Soeprapto. 1998. Ilmu Perundang-Undangan. Yogyakarta: Kanisius.

Moh Mahfud MD. 2006. Membangun politik Hukum, Menegakkan Konstitusi. Jakarta: LP3ES.

Muji Estiningsih. 2005. Fungsi pengawasan DprD. Yogyakarta: Universitas Atma Jaya.

Otje Salman dan Anthon F.Susanto. 2004. Beberapa Aspek Sosiologi Hukum. Bandung: Alumni.

Philippe Nonet dan Philip Selznick. 2008. (terjemahan), law and Society in Transition : Toward responsive Law. Bandung: Nusamedia.

Sadu Wasistiono dan Yonatan Wiyoso. 2009. Meningkatkan Kinerja Dewan perwakilan rakyat Daerah. Bandung: Fokusmedia.

Siswanto Sunarno. 2006. Hukum pemerintahan Daerah Di Indonesia. Jakarta: Sinar Grafika.

Syaukat Tabrani. 2003. Manajemen Pemerintahan Daerah Menuju Pemerintahan Efektif dan Efisien, Bandung: Armada.

Yuliandri. 2009. Asas-Asas Pembentukan Peraturan Perundang-undangan Yang Baik. Jakarta: Raja Grafindo Persada. 